\title{
The Capitalist Socius and Videogame Production: Autopoietic Subjectivation Monsters
}

\author{
Joshua Jackson \\ Staffordshire University
}

Abstract: Diverse representations of bodies in videogames have become a point of contention among developers and consumers alike, which has led scholars to question why videogame production is breaking with trends of recognizable, anthropocentric characters in favor of "diverse" bodies. This paper contends that the overarching reason for this is that the capitalist socius (Deluze and Guattari, 1986) has become more readily equipped to be able to monetize and streamline diversity. Instead of diversity and inclusivity in videogames being an act of subversion that was often only done outside of formal videogame production, the capitalist socius and videogame production have adapted the necessary material discursive apparatuses to turn diversity into a form of capitalgeneral. The mechanisms by which videogame production recruits and retains workers via their passion also offers insight into how these material-discursive apparatuses are forming. In examining how the capitalist socius overlays onto the videogame production process, a few things become apparent. Because videogame production operates within the capitalist socius, its goals are similar: to become autopoietic (able to reach a point of homeostasis in which the entity is able to reproduce and maintain its structural integrity), and to turn any and all resources into sources of capital generation. The expectation of bodies working in these regimes is to be as non-threatening and as pliable to new modes of subjectivation and capital generation as possible, but that means that bodies must undergo certain political transformations to adhere to these needs of the capitalist socius and videogame production processes.

In recent years, representations of diverse body types in videogames have become a point of contention for many North American triple-A videogame developers. For example, BioWare's popular series Dragon Age and Mass Effect offer players both heterosexual and homosexual romance options and have pushed back on anthropocentric character design to some extent. There is concern that these attempts at diversity are simply these companies trying to monetize diversity with no care given to how these representations actually affect consumers (Condis, 2015; Behm-Morawitz and Mastro, 2009; Polo, 2017). These sudden shifts in design choices raise some questions: Why are developers suddenly breaking nearly 40 years of character-creation tropes that dictate recognizable, identifiable, homogenized and anthropocentric characters? Why is diversity often poorly rendered and seemingly an afterthought? These representations of diversity indicate that the industry views both real and virtual bodies as objects of capital-generation. As issues of social justice and equity have become important points of discussion in videogame production (Chess, Evans, and Baines, 2017; Chess, 2016; Fisher and Harvey, 2013), companies have started flipping pre-rendered assets to appear equitable and inclusive. An example of this is the first Mass Effect's main character, Shephard. Regardless of what gender the player chooses for Shephard, the game still hails the player as male, and presents male-coded dialogue options. Until the market started to see the opportunity to market representations, hyper-masculinity, hypersexualized female bodies, and 
general anti-feminism were tools for commercial success (Behm-Morawitz and Mastro, 2009, Kennedy, 2002). Games like Tomb Raider drew popular media speculation and feminist speculation due to Sega's marketing strategy for the game, which involved playing up the sexual aspects of the protagonist Lara Croft (Kennedy, 2002). Questions of hypersexualization and its effects on both young boys and girls were raised, as were assertions that this hypersexualization could act as a point of sexual liberation and equality. A strong woman protagonist, though obviously sexualized through scant clothing, is still doing affective and physical labour, such as killing and pushing the human body to its limits, that had been mostly reserved for male leads in a male-coded media.

The spaces in which triple-A games are made are oriented around male bodies because most of the workers in triple-A development spaces are male (Johnson, 2013b; Dyer-Witheford and De Peuter, 2006). Returning to the example of Tomb Raider, Core Design, the company who created Tomb Raider, was made up of six people, five of them men, and one of them (the scriptwriter for the game), a woman. All concept art, initial sketches, characterization, etc. of Lara Croft were created by men (Sawyer, 1997). In today's videogame production apparatus, it is no different. According to the IGDA 2017 members' survey, roughly $80 \%$ of respondents were male, and $20 \%$ of respondents were women [IDGA, 2017]). The perpetuation of hypermasculinity and the necessity of dominance within videogame production spaces creates an environment that, as D'Anastasio (2018) says of Riot Games, is ultimately built for a male gaze and only concerned with male advancement: both of bodies into positions of leadership, and of male-coded ideology.

I contend that the main reason that the videogame industry is attempting to incorporate diverse material into games is that the capitalist socius (Deleuze and Guattari, 1983) is becoming better equipped to consume and monetize forms of diversity more readily. In short, 'diversity' has reached a critical mass in popular culture which means it is more profitable to include non-normative ideas and bodies (albeit, these inclusions are often poor representations and often insultingly characterized [Polo, 2017]) than it is to continue creating only hypersexualized, racist, homo- and transphobic material. The capitalist socius is developing the materialdiscursive circumstances that are required to spin often-demeaning characterizations of queer, non-normative, feminine, and bodies of color as positive and forward-thinking inclusions. This makes it seem as though videogame production companies are keen on tapping more diverse audiences when, in actuality, diversity presents another avenue of capital-generation with minimal effort or expenditure. According to Deleuze and Guattari (1983), the capitalist socius is a social 'body', or an assembly of productive, social entities, that are responsible for production of resources. In the case of late-stage capitalism and videogame production, the resource being produced is monetizable units of cultural production. The videogame production industry is firmly ensconced in systems of capitalism: precarity in production labor that forces workers to work themselves well past exhaustion or face replacement (Bulut, 2014 and 2015; Kerr and Kelleher, 2015; Williams, 2013 and 2018; Westar and Legault, 2017), outsourcing to third-world asset firms (Hyman, 2008), and the use of passion for videogames as an industry recruitment and retention tool and as a gate keeping mechanism for employee progress (Bulut, 2014 and 2015; Johnson, 2019; Deuze, Martin, and Allen, 2007; Kerr and Kelleher, 2015; Kuchlich, 2005; Sotaama, 2007; Parker, Witson, and Simon, 2017). The work hours during production cycles are grueling (Johnston, 2013b; Dyer-Witheford and De Peuter, 2006; Bulut, 2014 and 2015; Llerena, BurgerHelmchen, Cohendet, 2009); the work environments reinforce negative binaries such as hyper-masculinity and anti-feminism (Johnston, 2013a; Fisher and Harvey, 2013; Hacker, 1979 and 1981; Salter and Blodgette, 2012), 
and human bodies are readily axiomatized as sources of capital (Jenson and de Castell, 2018; Gallagher et al, 2017; DiSalvo et al, 2007). This means that, as social and cultural issues reach a threshold of recognizability in society at large, the bodies in question in that movement become more easily subjectivizable and exploitable.

I will provide a quick contextualization and explanation of a few key terms that I use in this paper. I am taking 'hypermasculinity' to mean what Mosher and Sirkin (1984) identified as an attitude or state of mind that a) exhibits a callous sexual attitude toward women, b) believes that violence is manly, and c) that experiencing danger is exciting. By using this definition, hypermasculinity in videogames doesn't just become a pejorative term to deride machismo, but instead becomes a checklist by which we can assess videogames, people, and workplace cultures. By referring to 'body', I am referring to multiple different understandings of what a body is/what constitutes a body: a human body, or a worker, or videogame production worker, refers to an organic human body and does not reference technical attachments or becomings unless otherwise noted (for this definition, I am mostly working off of Grosz' work around bodies [1994]). The capitalist socius (or capitalist body) refers to a social body defined by Delueze and Guattari (1983) that relies on outside means to overload bodies with information, or overcode, and to force those bodies into willingly perpetuating the cycle, or subjectivation, of the product that is being created. Videogame production is both a body and an assemblage. On the one hand, it is a generalized apparatus that can facilitate becomings between technical and non-technical production bodies and the capitalist socius, has its own agencements and contours, and has its own productive agenda. On the other hand, videogame production has its own dynamic intensities that it is constantly tapping the molecular bodies within it to try and make sense of chaos (Grosz, 2008). By referring to 'passion', I am taking it to mean a strong inclination towards certain activities over others that acts as an agent of influence regarding choices, relationship-building, or pursuance of certain paths of education or vocational training (Murnieks, Mosakowski, and Cardon (2012).

Passion regarding videogames takes a few forms. Being committed to fully experiencing the depth and complexity that a certain game offers, spending a majority of free time playing certain games and forming social bonds within the game to other players or even to non-player characters, or referencing, participating in, or creating unremunerated content for a game all constitute examples of 'passion' for videogames. This segues into 'passion' regarding videogame production quite well and explains the methodology by which recruitment-viapassion is so insidious. As Murnieks, Mosakowski, and Cardon (2012) say, 'passion' can be a reason for choosing a certain vocation.

\section{Structuration, 'Passion', and Videogaming without Organs}

It is important to this project to make clear that 'structuration' in the sense of Giddens' (1984) work has its place, but needs careful consideration. For Giddens, structuration sought a middle-ground between molar and molecular societal analyses. Structuration sees an immovable intersection between 'actor' and 'structure' that can be pinpointed to determine some deeper truth, or some deeper rationale for the interaction. It is exactly this determinism and rigidity that renders this sort of ontological turn ultimately useless for this project except for understanding how passion and videogame production intersect. Deleuze and Guattari are not searching for any deeper meaning than a set of interactions, for those interactions are the meaning. Resch (1992) says of Deleuze and Guattari's steps towards antistructuration:

For Deleuze, ontology is difference: the essence of all being is plural, productive, and devoid of deeper unity or meaning. Behind every thing or idea there are differences, yet behind difference there is nothing. By ontologizing the concept of difference, Deleuze seeks to escape from the labyrinth of absence and presence that envelops discursive practices, and it is this illusion of absence that serves as the (anti-) foundation of his thought. (230) 
My use of 'passion' as a sort of connective tissue in this paper is not an articulation of a place where 'actor' (body of some sort) meets 'agent' (in this case, videogame production). The main intersection of agent and structure that I am looking at here is that of 'passion' and 'recruitment' within videogame production and why this exact coordinate is so important to keep in mind when thinking through how the capitalist socius overlays onto videogame production and the ultimate goal of both: autopoiesis.

Before discussing how the capitalist socius overlays onto videogame production, it is important to talk about 'videogame production' and recruitment methods used in videogame production. Both of these topics present important differences from other forms of media production that are often overlooked or misunderstood.

Videogame production in and of itself represents a production media where both professional (e.g. on payroll for an indie company or a triple-A company) and non-professional (e.g. hobbyists, hackers, modders, and oneperson studios) videogame producers can see widespread success. Not only is there a plethora of low-cost or free videogame production tools, such as Twine, RPGMaker, GameMaker, Unity, and Unreal, but there are also multitudes of videogame production books that can help developers craft new, out-of-the-box ideas (e.g. Isbister's How Games Move Us, 2017; Rusch's Making Deep Games, 2017; and Flanagan and Nissenbaum's Values at Play in Digital Games, 2016). Additionally, platforms such as Steam, the Epic Store, and itch.io allow creators of any stripe to distribute their games to a potentially huge audience, both for profit and not-for-profit.

Unlike other media production apparatuses such as filmmaking or photography, videogame production's unique kit of production platforms and distribution platforms create an environment where success can be experienced by anyone in accordance with neoliberal ideology like allowing the monetary or cultural success of a game to determine its validity. This fundamental decentralization of a definitive, defined body of videogame producers that one must go through to experience commercial success creates an environment where 'success' and the ability to 'make it' without having institutional backing is ultimately in the hands of whomever is making the game. It also presents an environment where certain worker protections such as unionization require much more thought, planning, and action to even take root.

Videogame production in any form covets time devoted to a project as a way of gauging the amount of passion being given to a project. Videogame production's labor schedules and pipelines in many triple-A and indie development studios are created around expected periods of crunch (Dyer-Witheford and DePeuter, 2006), or periods of work where workers are expected to put in sometimes as much as 16 hours of work a day for an extended period. Additionally, recruitment methods for videogame production at all corporate levels (community management, quality assurance, programming, art and sound, etc.) rely on, first, appealing to a potential worker's passion for playing videogames, and then exploiting that passion. Berlant's concept of cruel optimism (2012) does a good, if somewhat deterministic, job of describing the cycle that videogame production perpetuates. Videogame production is touted as a 'do what you love' endeavor (Tokumitsu, 2014) where, the more labor you put into the apparatus of production, the more opportunities you have for advancement. Todd Howard's rise to fame with Bethesda is often peddled out as a case study when informally talking about passion and meritocratic advancement in videogames (Jackson, forthcoming). In multiple interviews, he presents his foray into production as him allowing his passion for videogames to lead him, him being dogged and determined to make a name for himself (Game Informer, 2011), and him being rewarded accordingly. Meritocracy, seemingly, did not fail Todd Howard in the way that it has failed many, many other production workers in the form of unfulfilled promises to hire on contingent workers, provide more stability for contingent workers, and advance 'diverse' people into positions of power within videogame production (Paul, 2018). Cruel optimism in videogame production sees 
young bodies that are passionate about playing videogames or interacting with videogame culture being recruited, and then their passion is turned into a subjectivation tool to force them into accepting periods of crunch (Bulut, 2015; Johnson, 2013a) because they want to advance or feel obligated to.

By distinguishing how labor differs from general media production, it is possible to understand in a more meaningful way what possible intensities, contours, and potentials videogame production has, and how the capitalist socius preys on the potentiality therein. Deleuze and Guattari's conception of a 'Body without Organs' (Deleuze and Guattari, 1983),' or BwO, presents a way of exploring these potentialities. It is not enough to describe one production company or one worker or one type of game as a way of characterizing all of videogame production. Instead, it is important to understand the entanglement that each worker, each game, each production company has with similar bodies; the potential becomings of, and intensities present within, each body, technical or nontechnical, present an entirely new set of possibilities. BwO provides a way of touching and interacting with multiplicative possible becomings within videogame production by not isolating any one part of videogames or production and asking it to stand on its own merits, or to speak for an entire sector:

Deleuze and Guattari's description of the Body without Organs (BwO), which is invoked to demonstrate the insufficiency of describing bodies and the notion of subjectivity in terms of components (organs) possessed by those bodies. To know what a body can be is not as simple as knowing what it contains. Instead of organs, bodies "can be occupied, populated only by intensities." (Halm \& Rieder, forthcoming)

It is important to understand, first, the deeper interactions under the shiny veneer of videogame production, and second how BwO works to allow us to see interconnectedness within actors in the apparatus of videogame production. Passion, as I have said before, is the connective tissue that is operating within the becomings I am interested in in videogame production. Passion comes in many forms: passion for playing games, experiencing games (e.g. watching eSports, Twitch, Let's Plays), creating games, hacking games, modding games. Each of these forms of passion has its own affective attachments that the passion-holder (in this, a potential production worker) defines for themselves. The interaction of passion and recruitment, then, operates at many different intensities that speak to each potential worker's embodied experiences that shape their own passion. Passion asks of the passion-holder to perform a form of autopoiesis (Maturana and Varela, 1972) in order to maintain that passion. The goal is to keep being fulfilled by the activity at hand. But to attain that goal and to fend off burnout or loss of interest, the passion-holder must invest themselves in different and varied activities within the culture to continue feeling justified in having a passion for this thing. For example, if someone is passionate about watching Let's Plays, they likely have a variety of Twitch or YouTube channels that they follow that produce different content; one may be a YouTube channel specializing in scary games, another may be a Twitch channel that specializes in speed runs or fighting games. The thing that keeps the passion for experiencing games fresh is that these channels are constantly producing new content that, when the passion-holder interacts with them, creates a spatiotemporal bubble where every interaction, every mouse-click or button push, every thought, every affect that occurs is specific to that spatiotemporal moment. Passion, then, is not an amorphous blob that engulfs a concept. Instead, it is akin to a chain of paperclips: each paperclip added to the chain of passion represents an intensity or becoming that is personal to that moment. It is self-defining, and it is nothing more or less than the affect within that spatiotemporal moment anchoring itself to the previous spatiotemporal moment to continue the chain and continue the autopoietic nature of passion. 
If passion is this multifaceted, molecular chain of becomings, then recruitment must make sense of that passion, and understand how best to insert itself into the paperclip-chain so as not to break the chain, but to deterritorialize and reterritorialize flows of work (e.g. creating knowledge capital). Deleuze and Guattari (1980) refer to wasps attempting to copulate with orchids as an example of how certain interactions or becomings can be thought of as ways of de- and reterritorializing, or as a rhizome. This metaphor applies neatly to videogame production. If the goal of the capitalist socius is to achieve autopoiesis, continue subjectivating bodies so that they are amenable to knowledge production, and to have value surpluses of knowledge, and the goal of videogame production is to continue existing within the socius and benefiting from its structure, then the way that recruitment must operate is akin to the wasp and orchid. The orchid mimics and lures the wasp to it to assist in reproduction (what Deleuze and Guattari refer to as a signifying element): images of having fun while you work, doing what you love, the cultural clout of working in videogames. We can understand this beaconing as recruitment. The fervor with which the wasp attempts to copulate with the orchid can be seen as passion, while each thrust, rub, or death can be seen as the interlinking passion paper-clips. The pollen that is transferred from orchid to wasp is the capitalist socius exploiting that passion and the signifying elements that appeal to the worker by embedding subjectivating elements into that paper-clip chain. These interactions are forming a map of possible intensities and becomings between worker, knowledge production, and passion, possible entries and exits that exist purely to accommodate new forms of passion, new forms of production, new platforms, and new ways of interaction between these elements.

\section{The Capitalist Socius, Videogame Production, Integrated World Capitalism}

Deleuze and Guattari (1983) provide a way of contextualizing how capitalism, as a social construct, came to be through characterizing the historical transformations of property ownership and ruling relations as first a 'savage' socius, then as a 'despotic' socius, and finally, as a 'capitalist' socius. The savage socius was organized around tribal relations: bodies are marked in ceremonies, which then insert those bodies into 'clans' from which products are traced. Land is claimed by tribes; that land is credited with production of materials in a symbiotic relation to the clan itself. As societies set down roots, and land claims became more routinized, the despotic socius formed. As land is amassed, warred over, and conquered, clan-land production loses its claim and instead empire-rule is the way of the world. As more land is acquired and mixed together, single-clan claims for production are no longer honored, and thus a new attribution model needed to be made. In the despotic socius, this became the despot, or the divine father of the people over whom he ruled. Production (in this case, production means land seizure as well as actual, material production) is attributed to the despot. The capitalist socius is a complete departure from the savage and despotic sociuses that Deleuze and Guattari discussed in Anti-Oedipus (1983). Whereas the savage and despotic sociuses were concerned with acculturating their citizens, and establishing hierarchies of dominance, the capitalist socius's main goal is production, and it relies on outside means to overload bodies with information, or overcode, and to force those bodies into willingly perpetuating the cycle, or subjectivation, of the product that is being created. In the case of this paper, I am speaking of videogame production in relation to the capitalist socius, not as a competitor or separate entity, but as a companion to it. The capitalist socius overloads bodies with cultural markers regarding videogames (they're fun, they're cool, when you make them all you do is play at work, etc) to overcode those bodies into become productive bodies that must adhere to the idea that videogames, and videogame production, have to be the way that they are, and must be guarded, lest their form of subjectivation that is allowing them to survive in capitalist society becomes threatened. 
By quantifying production in the sphere of videogames, the capitalist socius creates a space where the inherent purpose of the bodies that work within it is to connect deterritorialized flows of labor, meaning that instead of working toward a community's communal interest, like in the savage and despotic sociuses, workers are subjectivated to overproduce and not expect to take part in the bounty of overproduction. The excess that is produced is not redistributed equally to workers, but instead is hoarded by a select few bodies. This hoarding is done in a bid to further strip the identities of the bodies working within the capitalist socius and to create bodies that are conditioned to produce, expect little in the way of recompense, but always have the proverbial carrot on a string of "one day you too could own your own studio or make your own game, you just have to work harder."

Peticca-Harris et al (2015) talk about the extreme working conditions of the videogame production process by examining two very well-known whistleblowing blog posts from spouses of game developers at triple-A studios: the EA Spouse blog and the Rockstar Spouse blog. Both describe long periods of crunch, abusive management, and in-fighting due to stress that the spouses of the blog-writers endured. Burnout, depression, and health- and family-related problems are all very real possibilities of working in the industry (Johnson, 2013; Dyer-Witheford and de Peuter, 2006; Bulut, 2014 and 2015; Williams, 2013b and 2018). These conditions are due in large part to the working expectations of videogame production. Lionhead Studios' buy-out by Microsoft and subsequent shuttering is just one example of hundreds where the capitalist socius acquires a potentially productive body and attempts to regulate it, but does not account for the molecular differences in desiring-production of each worker, and the entity's desiring-productive circuit board over all. In this case, Lionshead failed to produce adequately subjectivizable bodies to do the work that Microsoft wanted which, in turn, failed to produce the value surplus of knowledge that Microsoft needed to consider the acquisition valuable.

The bodies at work creating and developing videogames are not the only bodies being remade by the videogame industry. In The Three Ecologies (1989), Guattari discusses the concept of integrated world capitalism (IWC), which Pindar and Sutton, in the translator's notes, define as:

Post-industrial capitalism - which Guattari calls Integrated World Capitalism (IWC) is delocalized and deterritorialized to such an extent that is impossible to locate the source of its power. IWC's most potent weapon for achieving social control without violence is the mass media. (4)

In the case of videogame production and consumption, the television set, as Pindar and Sutton reference, is not the point of entrance: instead, we must look at the global networks behind the videogames we consume. In addition to the devastatingly stressful environments that videogame production takes place in, a good portion of that work is outsourced, contributing to further job instability and precarity. Paul Hyman (2008) examines how the outsourcing practices of videogame art were an early harbinger of things to come. The company he profiles, THQ (today known as THQNordic), is a multi-billion dollar triple-A videogame producer that refers to outsourcing as 'distributed development.' Hyman references THQ having outsourced $20-25 \%$ of their art asset development in 2008, whereas today they outsource somewhere around $80 \%$ of their art asset development. Their in-house production is now primarily game systems, proprietary art assets, and marketing/branding. THQ's rampant outsourcing speaks to both the nature of the capitalist socius and of the videogame production process: what you keep in-house will end up costing you more than outsourcing. The majority of the art assets that THQ's internal developers outsource are to developing countries with burgeoning tech sectors like India, and increasingly Eastern Europe; this means that, for what would cost these internal developers millions of dollars to develop in-house, they can outsource for it to be developed for a fraction of that price. 
In addition to the physical labor the bodies in question in videogame production engage in, the immaterial labor invested in games is another important aspect of IWC. Lazzarato defines immaterial labor as "the labor that produces the informational and cultural content of the commodity" $(2010,132)$. Constance Steinkuehler (2006) wrote about the international distribution and privilege of play in Lineage. She profiles the "Chinese farmer" ${ }^{\text {"[1] in }}$ Lineage II:

For-profit companies in China were hiring people to play Lineage II for virtual currency in exchange for real-world pay. The practice continues largely unchecked today, and the attending controversy has nothing but intensified. [...] As best as I can piece together, Chinese adena farmers normally work 12-hour shifts... with two people to each computer so that the in-game character they share is always online. Typically, they must collect 300,000 adena per shift in exchange for their daily wage of about US $\$ 3$. It may not sound like much, but compared to China's average yearly income of US \$316, it's rather lucrative work.

Julian Dibbell (2016) built on this work, addressing the issues of whether paid gold farmers are players, and whether unpaid farmers are employees, echoing many of the same questions that have been asked in modding discourse (Kuchlich, 2005; Sotamaa, 2007; Gallagher et al, 2017; and Lauteria, 2012). The immaterial labor taking place in both of these pieces further highlights the world-wide precarity of videogame culture: "playbour" (Kuchlich, 2005) takes place as a means of making a living in third-world countries while this work is sold to Western players for inflated prices; players who have the means can benefit and perpetuate the necessity of this labor by buying the gold and items these people farm, which gives those players an inherent advantage over other players.

Dibbell and Steinkuehler don't consider the mechanisms of discipline that gold-farming sweatshops incorporate that further subjectivate the bodies laboring in those spaces: the spaces in which these bodies farm virtual gold resemble the development areas of many triple-A game studios. There is no sense of privacy, and the "fun" that is associated with playing a videogame is absent in much the same way as other unrecognized areas of videogame production: QA testing suffering burnout and job instability (Bulut, 2014; Williams, 2013), and community managers being expected to respond to community issues 24/7 (Kerr and Kelleher, 2015), to name a few examples. Both farmers and videogame production workers labor under conditions that do not value privacy: no partitions or cubicles, all the workers work in the open and are monitored by management; they have quotas to meet, and they work grueling hours to meet those quotas (see: Webster, 2018 for a discussion about Red Dead Redemption II's developers working 100 hour weeks to finish production). Both workspaces have a sense of panoptic control: the bodies laboring in these environments are being monitored, and should their work not be satisfactory, they can be replaced as quickly as they were hired.

\title{
Subjectivation Station(s)
}

Lazzarato, in Signs and Machines (2014), says that capitalism

\begin{abstract}
...reveals a twofold cynicism: the "humanist" cynicism of assigning us individuality and pre-established roles (worker, consumer, unemployed, man/woman, artist, etc.) in which individuals are necessarily alienated; and the "dehumanizing" cynicism of including us in an assemblage that no longer distinguishes between human and non-human, subject and object, or words and things. (13)
\end{abstract}

While capitalism is complicit in perpetuating binaries by creating and maintaining the material properties of bodily normativity by linking things such as gender to colors, masculinity or femininity to clothes and hygiene products, and masculinity/femininity to sports, it also allows rampant cultural subjectivation in other strata. For example, in 
the videogame production process, hypermasculinity, anti-feminism, and colonialism (white male saving a kingdom/town/woman from a non-human [read: non-white] threat) are common storylines in videogames. But the question remains: how, and why, are these tropes perpetuated, even in games that are supposed to be progressive and inclusive?

I want to start by addressing the binary of production/anti-production that Guattari references (1996). Antiproduction accounts for the things that are not getting made. Guattari refers to cinema as a medium of "transference, Oedipus, and castration" (235), meaning that cinema produces cultural markers by which bodies in modern society become subjectivated to value certain standards of beauty, products, religious forms, and other marks of enculturation so as to make these things profitable and able to be monetized. In other words, Guattari alludes to cinema as being a trend-setting affair. It creates the 'cool' things that drive supply and demand. The case can be made, too, that videogames operate in much the same way as cinema insofar as they both subjectivate consumers to value certain products, bodies, and forms over others, and create value systems that other media incorporate, adhere to, or run the risk of failing. The value systems that triple-A game production values and perpetuates are tropes of anti-femininity, hypermasculinity, colonialism, etc.

Videogame production processes subsist on, historically, keeping games that focus on personal, affective experiences out of mainstream production culture and instead, selling iteratively different content to quantifiable bodies (e.g. war games such as Call of Duty, Battlefield, Halo, etc. being marketed mostly to male, 18-35, heterosexual, white bodies). Current videogame production processes, though, are beginning to understand and recognize that affective and emotionally investing games can be monetized (Rusch, 2018; Isbister, 2017). So, whereas intimate, timely experiences that were rendered in videogame form used to be prevalent only in DIY and non-professional spaces (Fisher and Harvey, 2013), the capitalist socius has begun to develop the tools to consume and repurpose these game types in service of capitalism. In professional videogame development spaces, the bodies creating these affective experiences and attachments have not changed, either; in fact, the bodies in these spaces have stayed much the same (Westar and Legault, 2017; Williams, 2018; Fisher and Harvey, 2013). This has fostered an increasingly toxic and predatory work environment in which videogame production workers must labor under subjectivation regimes of not only being ok with creating and perpetuating anti-feminine, hypermasculine, colonialist, and anti-homo/transsexual media, but now also affectively and emotionally predatory media as well, further instantiating the dehumanizing cynicism that Lazzarato talks about by expecting workers to cede any moral judgments or objections to projects.

The cultural spaces that videogames inhabit have long been an "old boy's club" (Johnson, 2013a; Dyer-Witheford \& Sharman, 2005) in which women's bodies are marginalized - thought of as weak, needing to be rescued--while men perpetuate hyper-masculine tropes of killing and colonizing (Paaßen, Morgenroth, Stratemeyer, 2016). Women are attacked and their validity, personal and professional, is called into question (Fisher, 2015; Kerr and Kelleher, 2015). They are ignored as audiences; thought to just be "...vacant pinups to be ogled or irrelevant sidekicks to be tolerated, and real women [are] annoying interlopers to be bullied" (Fisher, 2015). Even in instances of attempted diversification (Fisher and Harvey, 2013), women's professional wants and needs are often ignored and downplayed.

Videogame production spaces are no better than most other cultural spaces concerning videogames where gender inclusivity and diversity are concerned. Johnson (2013a) talks about hyper-masculinity and the "boy's club" mentality of videogame production as something that: 
some men...lamented..., [but] many of their explanations centered on the idea that the gender imbalance is simply due to the fact that more men than women apply for jobs in the industry. [...] other men offered a clearer window into the sexism of the digital play industry, explaining, for example, that 'girls' often do not have 'the right ideas' when it comes to games but that it 'looks good' for a developer to employ 'some girls...'. (579)

Not only are the culture and working spaces of videogame production hyper-masculine and homogenous, but that gender imbalance is what allows the industry to function in the highly racialized and gendered manner that it does. The temporal dimensions of the highly gendered and racialized nature of production spaces are not locked in splintered, non-connected events; the subjectivation of workers to include tropes that perpetuate dominance of one body type over another exists as a corporate culture and climate, not as one or two peoples' opinions that somehow manage to sneak into games. From conceptual stages through creation, conscious aesthetic choices determine the continuity or usurping of hypermasculinity in both the production spaces, and in the products themselves (Johnson, 2013a).

Change in these realms does not happen with any urgency. Videogame production spaces are risk-averse and are often so locked to capitalistic production cycles that even if a studio wanted to rehabilitate its culture, often that cannot happen due to the nature of stagnation that the capitalist socius favors. Simply put, slow, incremental changes to videogame IPs and genres are prized over innovation and newness, both in triple-A production spaces and indie production spaces (Johnson, 2013b). This perspective speaks to the Guattarian (1989) notion of heterogenesis as being

an active, immanent singularization of subjectivity, as opposed to a transcendent, universalizing and reductionist homogenization $\ldots$ an expression of desire, of a becoming that is always in the process of adapting, transforming and modifying itself in relation to its environment. $(95 n 49)$

Heterogeny and iterative design are locked together in videogame production because they are part and parcel of what Guattari referred to with cinema (Guattari, 1996): videogame production is an enculturation endeavor and is responsible for subjectivating large sectors of the population. Capitalism has allowed videogame production to target certain audiences, readily subjectivize them to accept certain bodily, racial, and sexual portrayals as valid. Any attempt to break with those readily recognizable tropes would mean that the entire industry would have to radically reformat not only itself, but to whom it is marketing or risk the entire medium crumbling in on itself from alienating faithful consumers. This is, again, seen played out in the culture of videogame production spaces. The bodies at work creating the subjectivizing material have themselves been subjectivized to some degree into accepting the validity of only certain bodies for the medium, and, whether consciously or not, that subjectivization has embedded itself in workplace cultures that actively favor (mostly white) straight men for meritocratic purposes (D’Anastasio, 2018).

Large developers encourage heterogeneity throughout their studios. If the production processes and workflows are similar, it is easier to identify where and when a system is breaking down so that it can be rectified (Neilson and Rossiter, 2005; Brooks, 1974; Crowley et al, 2010). If the workspaces are similar, it follows that, as more heterogenic elements are incorporated into the life of a studio, even games from different genres will start to emulate one another's systems and become mixed-genre media. And just as the games become more similar, the bodies that make those games are expected to become more similar. This is where the tropes of hypermasculinity 
and anti-feminism and anti-individualism start to become apparent. Dyer-Witheford \& de Peuter (2006) state that "for many, the initially enjoyable aspects of work in digital play mutate into a linchpin of exploitative and exclusionary practices, including exclusion based upon gender."

Gender moderation is another aspect of production culture that contributes to the precarity of videogame production and perpetuation of negative tropes. Prescott and Bogg (2011) find that gender segregation is still happening in triple-A production spaces, and that women who do enter the industry must renegotiate their gender identity in order to fit in better with male coworkers (Johnson, 2013a and 2018). Johnson (2018) outlines how, if they do not do the work of renegotiating, they run the risk of being accused of being "fake gamers" (Taylor, Jenson, and de Castell, 2009; D'Anastasio, 2018) and have their passion called into question. This further demonstrates an unwillingness on the part of male production workers to accept alternate forms of passion to their own, alternate forms of bodies, and what those bodies are capable of.

The act of renegotiating gender in videogame production spaces becomes an act of subsistence rather than the more modern act of subversion that queer theory has attempted to recast it as (Butler, 1990; Halberstam, 2011; Munoz, 1999). In modern culture, gender fluidity is recognized and is becoming more and more accepted, and bodies are free to express their gender how they see fit. In processes of capitalist subjectivation though, nonmale bodies, or bodies that are not willing to perform the necessary gender renegotiating to become-male (Guattari, 1996,) become a hindrance. In an interview Johnson (2013a) conducted, he was able to extract a clear look at gender in the videogame production process:

other men offered a clearer window into the sexism of the digital play industry, explaining, for example, that 'girls' often do not have 'the right ideas' when it comes to games but that it 'looks good' for a developer to employ 'some girls.' (579)

The necessity of women to renegotiate their femininity, or to become-male, to be taken seriously and valued in the videogame production process presents a very troubling look at how gender is performed in these spaces, and how videogame production's workplace culture has come to recognize only one certain type of body as acceptably axiomatizable.

\section{Surviving to Win, and Winning to Survive}

In the case of biological bodies, capitalist socius, and videogame production bodies, the body that is experiencing autopoiesis is experiencing a continual rebirth and renewal of structures of investment. In the case of autopoiesis in videogame production, the renewal of structures of investment means that, as old production workers or disaffected workers or workers who are underperforming are removed from videogame production, new bodies with fresh passion are recruited and subjectivized. If the body is not experiencing autopoiesis, it degrades, the systems and infrastructure break down, and the body eventually ceases to exist. Thinking of autopoiesis as "the auto-reproductive capacity of a structure or ecosystem (Guattari, 2006, 93)," it becomes easier to imagine that the overarching goal of both the capitalist socius and of the videogame production process is simply to survive. They also seek to continue to create capital, perpetuate the tropes creating the capital, and to continue to subjectivate and consume bodies and ideas to create workers that will continue creating capital. These entities' goals of achieving maintainable autopoiesis play a large part in the continuity of the stereotypes 
and tropes of bodies that characterize videogame production and general capitalism. To subsist, the capitalist socius and videogame production both have to actively work to create new methods of subjectivation in areas outside of their consumptive radiuses.

Ergin Bulut (2015) profiles how utopian rhetorics of "fun," and "playbour" and "grassroots creativity efforts" regarding how working in the videogame production process have been utilized to draw in talented individuals. What the rhetorics don't address are the precarity and insidious nature of keeping a job in this industry. The company that Bulut (2015) profiles was once an independent videogame production space which was bought out by a conglomerate due to failing finances; when the first company was bought out, its entire workflow changed from making games that were interesting to them, to making games on the whims of "stock markets and decision-making processes at the corporate level, putting the developers 'in limbo, waiting to see what's gonna happen' as the management would tell [Bulut]" (195). Eventually, the once-independent company was deskilled and financialized into the workflow similar to what Johnson talked about regarding incrementalisation, and what Guattari referred to as heterogenesis. Most importantly Bulut noticed that, in addition to the steady decline of employed workers and the burnout experienced by all levels of workers, the corporate culture of the company became more and more divisive, exclusionary, and divided. The "above-the-line" workers (senior developers, project managers, CFO/CIT/C__ started to treat workers in mechanized ways. Nothing except work-flow was important, and "the introduction of project managers created conflict since project managers were seen as "cracking the whip across the board'” (Bulut, 2014). Bulut noticed, too, that as deskilling was occurring, the below-line workers complained of having to manage each other instead of producing the content they had been hired to produce. This peer-management went for such things as code documentation, documenting changes and edits in art assets, and even keeping peers motivated to actually do these things. The precarity of peermanagement, in addition to the sudden subjectivization of workers' bodies to become 'mechanical' and processdriven, financialization of the company, and deskilling of the workforce produced a negative feedback loop. For the few women that were present in Bulut's 2.4 years of fieldwork, most of them expressed increasing feelings of inadequacy and depression due to peer pressure to "do better, be better, and get better things done," and "stop letting emotions rule everything and just do the work" (198).

Bulut's example is only one case study of one videogame production company, but the literature that l've presented about the toxic workspaces of the videogame production process and the autopoietic, self-sustaining goals of the socius and videogame production process give backing to the thought that the labor being done in videogame production spaces stoke the flames of hyper-masculinity and anti-feminism. The male bodies that Bulut encountered in this company pushed emotion to the side and acted in mechanized ways, while the female bodies responded with emotion - the embodiment of the "strong men, weak women" trope.

\section{Moving Forward, (Re)doing Production}

Throughout this paper, I have outlined the various ways and means that the capitalist socius overlays with the modern triple-A videogame production process, how the two have similar goals and methodology for propagating and surviving through autopoiesis, and how hyper-masculinity and anti-feminism run riot in both.

In future work, it will be important to isolate and interrogate how passion is mobilized as a recruitment tool, especially since it seems counter-productive to the capitalist socius' goal of isolating and stripping autonomy and passion away from workers to streamline capital generation. To do this, research will have to follow in Robin 
Johnson's steps initially in interrogating how body politics are played out in videogame production spaces, but then take a more granular, molecular approach to understanding how production workers operate in those spaces. By interrogating these things, it will be easier to work towards a better understanding of how passion operates as one of the main driving forces that allow for continual abuse of workers, successful union-busting efforts by both managing entities and by anti-union workers, and whether the passion that drives workers is also responsible in some part for perpetuating tropes of anti-femininity and hyper-masculinity.

Additionally, and highly personally, it is important to continue keeping a watchful and critical eye on how videogame production is developing and where potential cracks are forming that would allow the capitalist socius access to practices that seek to upend it. There is a lot of good happening. Game Workers Unite, AnyKey's GLHF pledge, Dames Making Games, and Pixelles are examples of bodies working hard toward better working, helping women, queer bodies, and people of color gain the skills necessary to get into videogame production to keep making non-normative, personally-driven projects, and to reduce toxicity and violence in videogame culture. However, as this paper has demonstrated, there are negative things masquerading as positive ones, and things that seek to keep videogame production how it is: masculine, heterosexual, and hyper-violent. We must not fall into a habit of paranoid reading (Sedgwick, 2006) where we look at games or culture as unworkably negative. Instead, we must remember that the bodies laboring within these apparatuses are doing so because they are passionate about what they are doing, and they are doing so of their own volition. Moving forward, we must not denigrate those bodies, but find new ways of supporting them while also supporting efforts that are anti-capitalist and radically soft.

\section{Bibliography}

Alexander, L. (2014, September 05). Sexism, Lies and Video Games: The Culture War Nobody Is Winning. Retrieved July 19, 2019, from https://time.com/3274247/video-game-culture-war/

Anthropy, A. (2012). Rise of the videogame zinesters: How freaks, normals, amateurs, artists, dreamers, dropouts, queers, housewives, and people like you are taking back an art form. Seven Stories Press.

Behm-Morawitz, E., \& Mastro, D. (2009). The Effects of the Sexualization of Female Video Game Characters on Gender Stereotyping and Female Self-Concept. Sex Roles, 61(11-12), 808-823. doi:10.1007/s11199-009-9683-8

Berlant, L. G. (2012). Cruel optimism. Duke University Press.

Brooks, F. P. (1974). The Mythical Man-Month Essays on Software Engineering. Addison-Wesley.

Bulut, E. (2014). Playboring in the Tester Pit. Television \& New Media, 16(3), 240-258.

doi:10.1177/1527476414525241

Bulut, E. (2015). Glamor Above, Precarity Below: Immaterial Labour in the Video Game Industry. Critical Studies in Media Communication, 32(3), 193-207.

Butler, J. (1990). Gender trouble: Feminism and the subversion of identity. Routledge. 
Chess, S. (2016). The queer case of video games: Orgasms, Heteronormativity, and video game narrative. Critical Studies in Media Communication, 33(1), 84-94. doi:10.1080/15295036.2015.1129066

Chess, S., Evans, N. J., \& Baines, J. J. (2016). What Does a Gamer Look Like? Video Games, Advertising, and Diversity. Television \& New Media, 18(1), 37-57. doi:10.1177/1527476416643765

Condis, M. (2014). No homosexuals in Star Wars? BioWare, 'Gamer' Identity, and the Politics of Privilege in a Convergence Culture. Convergence: The International Journal of Research into New Media Technologies, 21(2), 198-212.

Crowley, M., Tope, D., Chamberlain, L. J., \& Hodson, R. (2010). Neo-Taylorism at Work: Occupational Change in the Post-Fordist Era. Social Problems, 57(3), 421-447. doi:10.1525/sp.2010.57.3.421

Culver, K. B. (2018). A Magical Putter and the Year in Media Ethics. Center for Journalism Ethics. https://ethics.journalism.wisc.edu/2015/01/03/a-magical-putter-and-the-year-in-media-ethics

D'Anastasio, C. (2018). Inside The Culture Of Sexism At Riot Games. Kotaku. https://kotaku.com/inside-theculture-of-sexism-at-riot-games-1828165483

Deuze, M., Martin, C. B., \& Allen, C. (2007). The Professional Identity of Gameworkers. Convergence: The International Journal of Research into New Media Technologies, 13(4), 335-353. doi:10.1177/1354856507081947

Deleuze, G., \& Guattari, F. (1983). Capitalism and schizophrenia. Minneapolis: University of Minnesota Press.

Deleuze, G., \& Guattari, F. (1980). A Thousand Plateaus: Capitalism and Schizophrenia. London: Bloomsbury.

Dibbell, J. (2016). Invisible Labour, Invisible Play: Online Gold Farming and the Boundary Between Jobs and Games. Vanderbilt Journal of Entertainment \& Technology Law, 18(3).

DiSalvo, B., Yardi, S., Guzdial, M., McKlin, T., Meadow, C., Perry, K., \& Bruckman, A. (2011). African American Men Constructing Computing Identity. In Proceedings of the SIGCHI Conference on Human Factors in Computing Systems (pp. 2967-2970). ACM.

Dyer-Witheford, N. \& Peuter, G. S. (2006). "EA Spouse" and the Crisis of Video Game Labour: Enjoyment, Exclusion, Exploitation, and Exodus. Canadian Journal of Communication, 31(3).

Dyer-Witheford, N. \& Sharman, Z. (2005). The Political Economy of Canada's Video and Computer Game Industry. Canadian Journal of Communication, 30(2). doi:10.22230/cjc.2005v30n2a1575<

Eaton, J. (2016, April 11). Rep. Katherine Clark's Crusade against the Internet's Tormentors. The Christian Science Monitor. https://www.csmonitor.com/World/Passcode/2016/0411/Rep.-Katherine-Clark-s-crusade-against-theInternet-s-tormentors

Fisher, H. D. (2015). Sexy, Dangerous -- and Ignored. Games and Culture, 10(6), 551-570. 
Fisher, S. \& Harvey, A. (2013). Intervention for inclusivity: Gender politics and indie game development. Loading... The Journal of the Canadian Game Studies Association, 7(11).

Flanagan, M. \& Nissenbaum, H. F. (2016). Values at play in digital games. MIT Press.

Gallagher, R., Jong, C., \& Sinervo, K. (2017). Who Wrote the Elder Scrolls?: Modders, Developers, and the Mythology of Bethesda Softworks. Loading... The Journal of the Canadian Game Studies Association, 10(16).

Giddens, A. (1984). The Constitution of Society: Outline of the Theory of Structuration. Cambridge: Polity Press.

Guattari, F. (1989). The Three Ecologies. London: Bloomsbury Academic.

Guattari, F., \& Lotringer, S. (1996). Chaosophy. New York: Semiotext(e).

Guattari, F., Bains, P., \& Pefanis, J. (2006). Chaosmosis: An Ethico-Aesthetic Paradigm. Sydney: Power Publications.

Grasser, U., Zittrain, J., Faris, R., \& Jones, R. H. (2015). Internet Monitor 2014: Reflections on the Digital World: Platforms, Policy, Privacy, and Public Discourse. Berkman Center Research Publication, 2014-17.

Grosz, E. (1994). Volatile Bodies toward a Corporeal Feminism. Bloomington: Indiana Univ. Press.

Grosz, E. (2008). CHAOS, TERRITORY, ART: Deleuze and the Framing of the Earth. S.I.: Columbia University Press

Hacker, S. L. (1979). Sex Stratification, Technology and Organizational Change: A Longitudinal Case Study of AT\&T. Social Problems, 26(5), 539-557. doi:10.1525/sp.1979.26.5.03a00060

Hacker, S. L. (1981). The Culture of Engineering: Woman, Workplace and Machine. Women's Studies International Quarterly, 4(3), 341-353. doi:10.1016/s0148-0685(81)96559-3

Halm, Matthew, and David M. Rieder. "Touch-Interactive Rhetorics: Everting the Real Through Wonder in Movement." Re-Programmable Rhetoric, edited by Anthony Stagliano and Steve Holmes, Utah State University Press, forthcoming.

Halberstam, J. (2011). The Queer Art of Failure. Duke University Press.

Harvey, A. (2011). Constituting the player: Feminist Technoscience, Gender, and Digital Play. International Journal of Gender, Science and Technology, 3(1).

Hauben, M., \& Hauben, R. (1998). Netizens: On the History and Impact of Usenet and the Internet. First Monday, 3(7).

Hyman, P. (2008). OUTSOURCING: Video Game Art Is Increasingly “To Go.” Game Developer, 15(8). 
Informer, G. (2011, November 29). How Skyrim's Director Todd Howard Got Into The Industry. YouTube. https://www.youtube.com/watch?v=xoYDjzGN44Y

Isbister, K. (2017). HOW GAMES MOVE US: Emotion by design. S.I.: MIT Press.

Jackson, J. (2020). Cruel Optimism and Neoliberalism in Videogame Production (Unpublished doctoral dissertation). North Carolina State University.

Jane, E. A. (2017). Misogyny online: A short (and brutish) history. SAGE.

Jenson, J., \& Castell, S. D. (2018). "The Entrepreneurial Gamer": Regendering the Order of Play. Games and Culture, 13(7), 728-746. doi:10.1177/1555412018755913

Johnson, R. (2013)a. Hiding in Plain Sight: Reproducing Masculine Culture at a Video Game Studio. Communication, Culture \& Critique, 7(4), 578-594.

Johnson, R. S. (2013)b. Toward Greater Production Diversity. Games and Culture, 8(3), 136-160.

Johnson, R. (2019). Technomasculinity and Its Influence in Video Game Production. In N.T. Taylor \& G. Voorhees (Eds.), Masculinities in Play. Palgrave Macmillan, pp. 249-262.

Kennedy, H. (2002). Lara Croft: Feminist Icon or Cyberbimbo? On the Limits of Textual Analysis. Game Studies, 2(2).

Kerr, A., \& Kelleher, J. D. (2015). The Recruitment of Passion and Community in the Service of Capital: Community Managers in the Digital Games Industry. Critical Studies in Media Communication, 32(3), 177-192.

doi:10.1080/15295036.2015.1045005

Kolhatkar, S. (2014). The Gaming Industry's Greatest Adversary Is Just Getting Started. Bloomberg. https://www.bloomberg.com/news/articles/2014-11-26/anita-sarkeesian-battles-sexism-in-games-gamergateharassment

Kuchlich, J. (2005). Precarious Playbour: Modders and the Digital Games Industry. Fibreculture Journal, 5.

Lauteria, E. (2012). Ga(y)Mer Theory: Queer Modding as Resistance. Reconstruction, 12(2).

Lazzarato, M. (2010). Immaterial Labour. In P. Virno \& M. Hardt (Eds.), Radical Thought in Italy a Potential Politics (pp. 133-151). Minneapolis, Minn.: Univ. of Minnesota Press.

Lazzarato, M. \& Jordan, J. D. (2014). Signs and machines: Capitalism and the Production of Subjectivity. Los Angeles: Semiotext(e).

Legault, M. \& Weststar, J. (2015). The Capacity for Mobilization in Project-Based Cultural Work: A Case of the Video Game Industry. Canadian Journal of Communication, 40(2). 
Lemons, M. A. \& Parzinger, M. (2007). Gender Schemas: A Cognitive Explanation of Discrimination of Women in Technology. Journal of Business and Psychology, 22(1), 91-98.

Llerena, P., Burger-Helmchen, T., \& Cohendet, P. (2009). Division of Labour and Division of Knowledge: A Case Study of Innovation in the Video Game Industry. Schumpeterian Perspectives on Innovation, Competition and Growth, 315-333. doi:10.1007/978-3-540-93777-7_18

Mantilla, K. (2015). Gendertrolling: How Misogyny Went Viral. Santa Barbara, CA: Praeger.

Mortensen, T. E. (2016). Anger, Fear, and Games: The Long Event of \#GamerGate. Games and Culture, 13(8), 787806. doi:10.1177/1555412016640408

Mosher, D. L. \& Sirkin, M. (1984). Measuring a macho personality constellation. Journal of Research in Personality, 18(2), 150-163. doi:10.1016/0092-6566(84)90026-6

Muñoz, J. E. (1999). Disidentifications Queers of Color and the Performance of Politics. University of Minnesota Press.

Murnieks, C. Y., Mosakowski, E. \& Cardon, M. S. (2014). Pathways of Passion: Identity Centrality, Passion, and Behavior Among Entrepreneurs. Journal of Management, 40(6), 1583-1606. doi:10.1177/0149206311433855

Neilson, B., \& Rossiter, N. (2005). From Precarity to Precariousness and Back Again: Labour, Life and Unstable Networks. The Fibreculture Journal, 5.

Paassen, B., Morgenroth, T. \& Stratemeyer, M. (2016). What is a True Gamer? The Male Gamer Stereotype and the Marginalization of Women in Video Game Culture. Sex Roles, 76(7-8), 421-435.

Parker, F., Whitson, J. R., \& Simon, B. (2017). Megabooth: The Cultural Intermediation of Indie Games. New Media \& Society, 20(5), 1953-1972. doi:10.1177/1461444817711403

Paul, C. A. (2018). The Toxic Meritocracy of Video Games: Why Gaming Culture is the Worst. University of Minnesota Press.

Peticca-Harris, A., Weststar, J. \& Mckenna, S. (2015). The Perils of Project-based Work: Attempting Resistance to Extreme Work Practices in Video Game Development. Organization, 22(4), 570-587.

Polo, S. (2017, April 05). BioWare details changes to controversial transgender NPC.

https://www.polygon.com/2017/4/5/15195416/mass-effect-andromeda-transgender-npc-changes

Prescott, J., \& Bogg, J. (2011). The Computer Games Industry. Women in Engineering, Science and Technology, 138-158. doi:10.4018/978-1-61520-657-5.ch007

Resch, R. P. (1992). Althusser and the Renewal of Marxist Social Theory. University of California Press. 
Riegle-Crumb, C. \& King, B. (2010). Questioning a White Male Advantage in STEM: Examining Disparities in College Major by Gender and Race/Ethnicity. Educational Researcher, 39(9), 656-664.

Rusch, D. C. (2017). Making Deep Games: Designing Games with Meaning and Purpose. Boca Raton, FL: CRC Press, Taylor \& Francis Group, an Informa business.

Salter, A. \& Blodgett, B. (2012). Hypermasculinity \& Dickwolves: The Contentious Role of Women in the New Gaming Public. Journal of Broadcasting and Electronic Media, 56(3).

Salter, M. (2017). GamerGate and the Subpolitics of Abuse in Online Publics. In Crime, justice and Social Media. London: New York: Routledge.

Sawyer, M. (1997). Lara hit in The Face.

https://web.archive.org/web/20070522021325/http:/www.cubeit.com/ctimes/news0007b.htm

Schreier, J. (2017). Blood, Sweat, and Pixels: The Triumphant, Turbulent Stories Behind How Video Games are Made. Harper.

Simon, R. M., Wagner, A. \& Killion, B. (2016). Gender and Choosing a STEM Major in College: Femininity, Masculinity, Chilly climate, and Occupational Values. Journal of Research in Science Teaching, 54(3), 299-323.

Sotamaa, O. (2007). On Modder Labour, Commodification of Play, and Mod Competitions. First Monday, 12(9). doi:10.5210/fm.v12i9.2006

Stanton, R. (2015). A Brief History of Video Games: From Atari to Xbox One. London: Robinson.

Steinkuehler, C. (2006). The Mangle of Play. Games and Culture, 1(3), 199-213.

Taylor, N., Castell, S. D., \& Jenson, J. (2009). Cheerleaders/booth Babes/ Halo Hoes: Pro-gaming, Gender and Jobs for the Boys. Digital Creativity, 20(4), 239-252.

Tokumitsu, M. (2014). In the Name of Love. Jacobin Magazine. https://www.jacobinmag.com/2014/01/in-thename-of-love/

Varela, F. \& Maturana, H. (1972). Mechanism and Biological Explanation. Philosophy of Science, 39(3).

Webster, A. (2018, October 15). Rockstar clarifies Red Dead Redemption 2 's "100-hour work week," following backlash. http://www.theverge.com/2018/10/15/17979606/rockstar-red-dead-redemption-2-crunch-100-hourwork-week

Weststar, J., \& Legault, M. (2017). Why Might a Videogame Developer Join a Union? Labor Studies Journal, 42(4), 295-321. doi:10.1177/0160449x17731878 
Weststar, Johanna, Victoria O'Meara, Marie-Josée Legault. Developer Satisfaction Survey, 2017. Canada: International Game Developers Association, 2017. https://www.igda.org/page/dss2017

Williams, I. (2003). "You Can Sleep Here All Night”: Video Games and Labor. Jacobin Magazine. http://www.jacobinmag.com/2013/11/video-game-industry/

Williams, I. (2018, March 23). After Destroying Lives For Decades, Gaming Is Finally Talking Unionization. Vice. https://www.vice.com/en_us/article/7xdv5e/after-destroying-lives-for-decades-gaming-is-finally-talkingunionization

Zulch, M. (2015, 27 Sept). “Lora Mathis.” Hooligan Magazine, pp. 16-23.

1. "Chinese farmer" in this context references a person, often of Asian descent, who works in sweatshop conditions killing in-game enemies over and over again to harvest gold that is then sold to other players for real-world money.

\section{Cite this Essay}

Jackson, Joshua. "The Capitalist Socius and Videogame Production: Autopoietic Subjectivation Monsters." Rhizomes: Cultural Studies in Emerging Knowledge, no. 36, 2020, doi:10.20415/rhiz/036.e05 